\author{
Acta Scientifica Naturalis \\ Former Annual of Konstantin Preslavsky University - Chemistry, Physics, Biology, Geography \\ Journal homepage: http://www.shu.bg
}

Received: 30.10 .2016

Accepted: 11.01.2017

\title{
Morphostructure of the Sakar and Strandzha Mountains
}

\author{
Tzanko Tzankov ${ }^{1}$, Svetla Stankova ${ }^{2}$, Rosen Iliev $^{3}$ \\ ${ }^{1,3}$ South-West University "Neofit Rilski" - Blagoevgrad \\ ${ }^{2}$, ,Konstantin Preslavski” University of Shumen \\ e-mail:tzankov1936@abv.bg;s_stankova@abv.bg;rosen_faust@abv.bg
}

\begin{abstract}
The Sakar and Strandzha Mountains are disposed in the South-East end of the Balkan Peninsula (on the both sides of the Bulgarian-Turkish boundary). They belong to the southeastern margin of the Bulgarian continental microplate. They are limit from North Thracian morphostructural zone to the North, the East Thracian morphostructural zone to the South and the Rhodopean morphostructural zone to the West. The observed mountain territory builds the Sakar-Strandzha morphostructural zone. It is divided by Sakar Dervent and Strandzha morphostructural areas. Every of them include morphostructural regions. They are composed by numerous Late Pleistocene-Holocene dome-like morphostructures. The relics from the Post Early Pleistocene concentric morphostructures are distributed in the entire zone. They were determined some archer and concentric Holocene mountain morphostructures.
\end{abstract}

The regional seismic activity (during the last 50 years) outlines three parts of the Sakar-Strandzha morphostructural zone. The western one - the Sakar part is moderate seismic active. The central - Dervent part is practically seismic ,calm”. The eastern one-Strandzha part show a very intensive seismicity. It can by given right in a future (after the necessary investigations) to divide the zone in three areas.

Key words: morphostructural units, morphostructural generations, mountain morphostructures

\section{Introduction}

The study propound the results of the authors' investigations about the morphostructure of the SakarStrandzha. Here are analyzed morphological characteristics of positive regional landforms as a real criterion of the nature and evolution of its morphogenesis. For this purpose were studied and compared species, morphological traits, spatial dimensions, vertical displacement and relationships between the morphographic units within the research area $[1,2,3,4,5,6,7,8,9,10,11]$.

Conducting of such research in the future would be an important criterion for assessing of the near-surface lithospheric geodynamic processes and trends in the changes to the local relief.

The propozed invstigation is based on:

1/ a complex morphostructural map (scale 1:250 000) of the Sakar-Strandzha morphostructural zone;

2/ an analysis of the character and evolution of the Sakar-Strandzha morphostructural zone during Late Neogene - Quaternary morphogene processes accordingly the modern concept of the listric tectonics and plate tectonics.

3 / regional seismic hazard as real criterion for the morphostructural division of the study area;

4/ it was analysis the former geological, geomorphologic and morphostructural investigations for the region (see the references).

The proposed investigation has a pionier character. The authors' reserve the right to expand or change some elements in his ideas or conclusions during the future investigations.

\section{Regional morphostructural dividing}

The Sakar - Strandzha morphostructural zone includes the lands located between Northern Thracian morphostructural zone to the north, the East Thracian morphostructural zone to the south and the Rhodopean morphostructural zone to the west (Fig.1). 
Within morphostructural zone dominated by hilly and low mountainous terrain, as middle mountainous relief has a small share. Despite the low altitude horizontal segmentation of the relief has large the valuesfrom 2,0 to $3,5 \mathrm{\kappa m} / \mathrm{km}^{2}$. The reason for that are widespread sedimentary and igneous rocks susceptible to erosion and deforestation and torrential rains during the winter. The vertical indentation of the relief is in the range from 50 to $200 \mathrm{~m} / \mathrm{Km}^{2}$.

In morphographic and seismic-tectonics (Fig.2) causes the Sakar-Strandzha morphostructural zone is divided into three areas: Sakar one, Dervent one and Strandzha one.

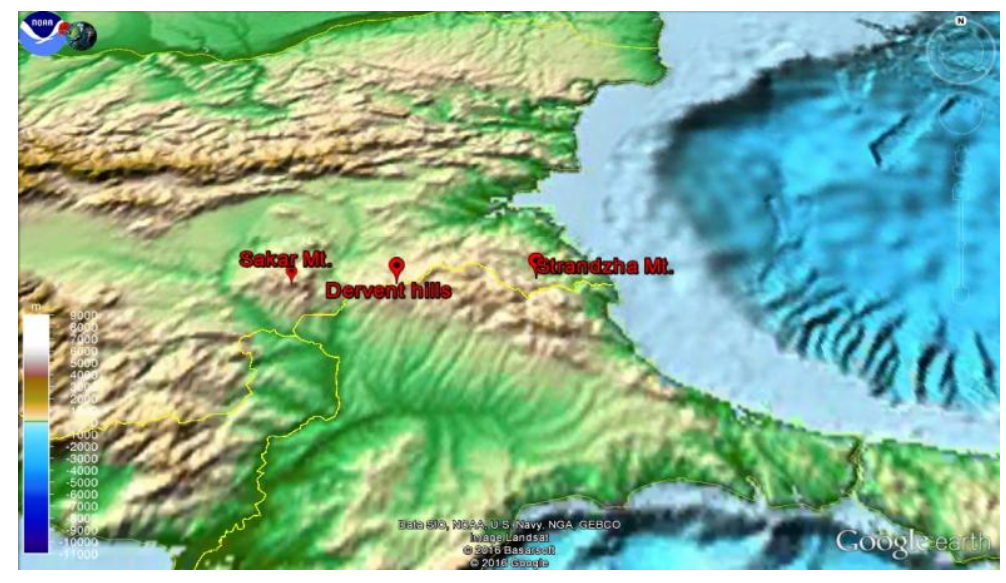

Fig. $13 \mathrm{~d}$ digital elevation model of the Sakar-Strandzha morphostructural zone (DEM Etop01-ice surface, NOAA; Basemap: Google Earth)

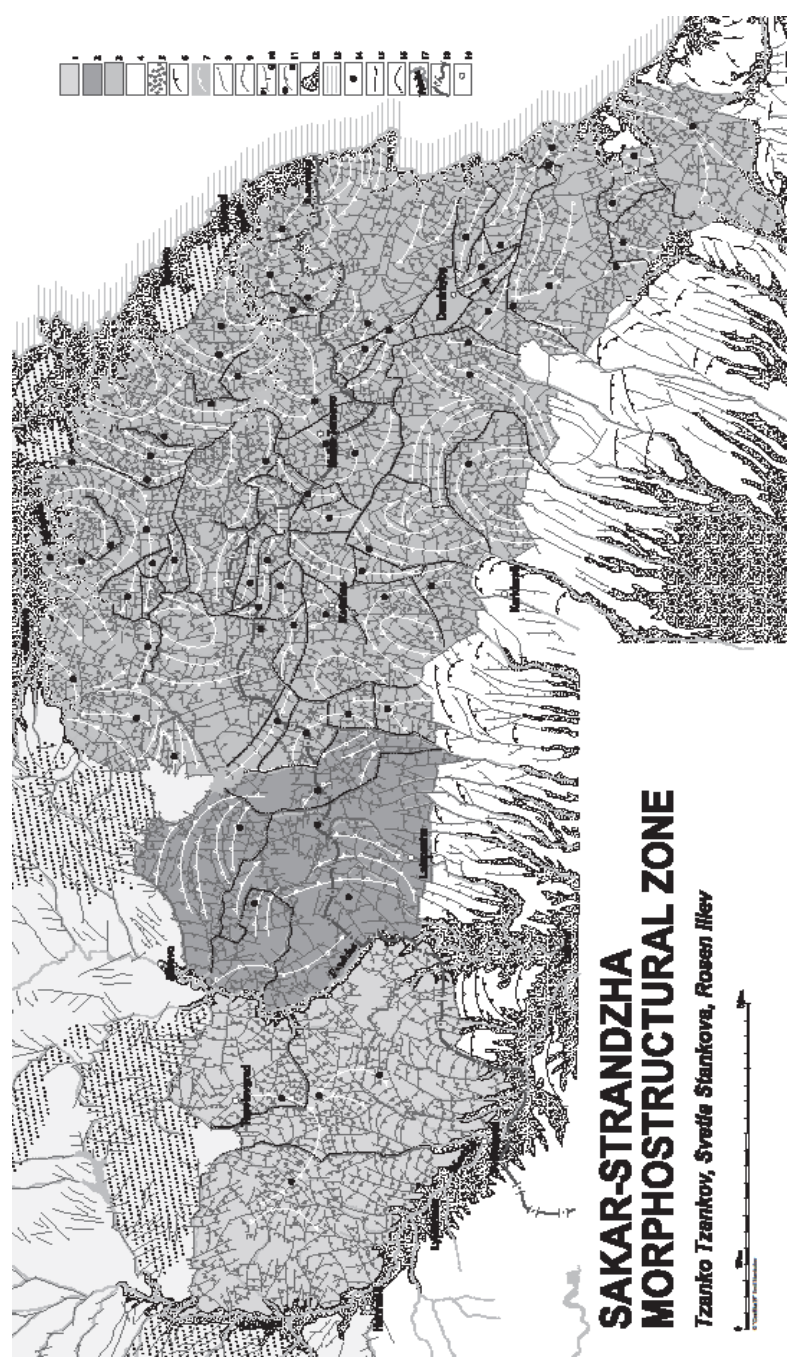

Fig. 2 Map of the Sakar-Strandzha morphostructural zone 
1-3 - Sakar-Strandzha morphostructural zone: 1- Sakar morphostructural area, 2- Dervent morphostructural area, 3- Strandzha morphostructural area; 4-5 - relicts from the Post Early Pleistocene Orthoplain: 4 lowlands, 5- buttes; 6- traces of the Post Early Pleistocene syneclises and anteclises, 7- traces of the Post Early Pleistocene concentric morphostructures, 8- faults, 9- supposed faults, 10- high angular (normal) faults, 11- low angular (listric) faults, 12- fault zone, 13- maximal contemporary uplifting center, 14- boundary between the morphostructural regions, 15- boundary between the morphounit groups, 17- outline and scope of the 100 meters terraces, 18- Bulgarian-Turkey frontier, 19- towns

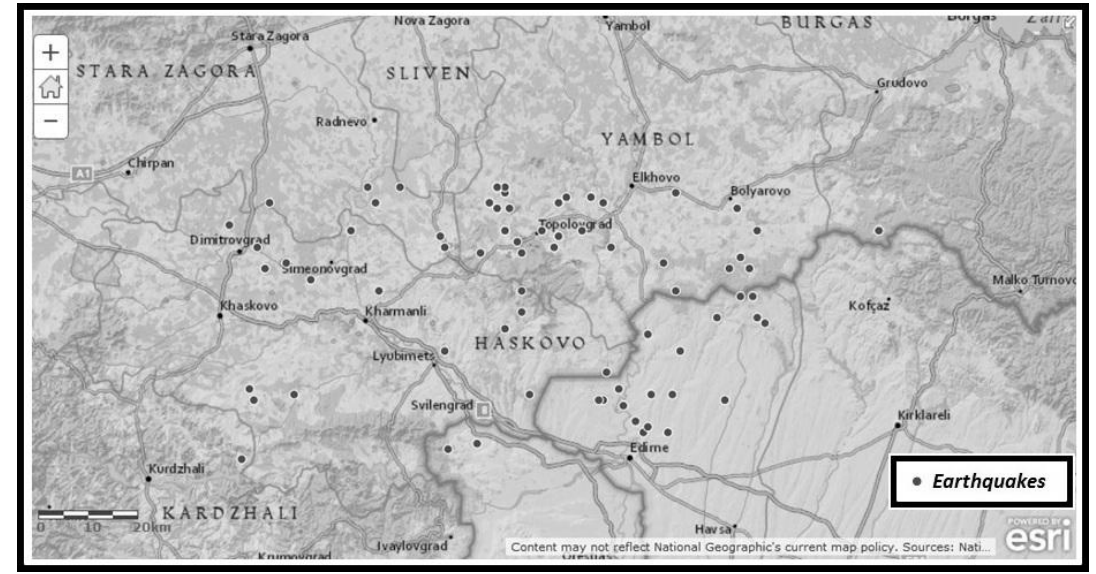

Fig.3 Map of the seismic activity in the research area over the past 50 years (all magnitudes). [11] Sakar morphostructural area

Sakar is a small mountain located between the valleys of the Maritsa $(472 \mathrm{~km})$ and the Tundzha River (390 $\mathrm{km})$. To the north the valleys of the small rivers Sokolitsa River $(61 \mathrm{~km})$ (a tributary of the Sazliyka River) and Sinapovska reka River $(50 \mathrm{~km})$ (Yavuzdere, a tributary of the Tundzha River) separates it from Monastery Heights $(600 \mathrm{~m})$. To the southeast of the territory of Turkey her final low ridges almost reached the town of Edirne.

Elongated dome of Sakar Mountain stretches in the northwest-southeast, as the length of the mountain is about $75 \mathrm{~km}$ and width up to $35 \mathrm{~km}$. The total area of the mountain is $1115 \mathrm{\kappa m}^{2}$ of which only a few dozen square kilometers remain on Turkish territory.

The main ridge of the Sakar Mountain has a rounded shape, in its northwestern corner is $600-700$ meters high. The largest slope gradients are in the range of $20^{\circ}-25^{\circ}$ on the eastern slopes of the mountain. The highest peak is Vishegrad peak $(856 \mathrm{~m})$. In the south the mountain decreases and gradually moves to the valleys of the Maritsa River and the Tundzha River.

Western and eastern slopes of the mountain are relatively steep, descending stepwise to valley depressions and are cut from thick, but slightly graven valleys network, that a significant part of the year is anhydrous. Are pronounced erosion processes, especially on the southwestern slopes of the mountain.

\section{Dervent hills morphostructural area}

Dervent hills are located on both sides of the Bulgarian-Turkish border. The majority of them are located in Turkey (about $60 \%$ of the total area). Stretch in the west-east (at a maximum width of $50 \mathrm{~km}$ ) between Srem Gorge of the Tundzha River to the west and Popovo River and Chengerlidere River to the east, which separate it from Strandzha Mountain.

The ridge of hills is flat and slightly hilly with altitude of $300-450$ meters above which rise rounded peaks, the highest of which is Gyurgenbair $(555,2 \mathrm{~m})$, located on Bulgarian territory.

\section{Strandzha morphostructural area}

Strandzha is a small mountain massif, located in the southeastern part of the Balkan Peninsula. It bordered on the north by Burgas Lowland, to the north-east and east with Black sea and to the south and south-west with East Thracean Lowland.

Strandzha morphostructural area is the spreading direction of northwest-southeast. Its length is about 125 $\mathrm{km}$, width up to $65 \mathrm{~km}$. The total area of the mountain massif is about $10,000 \mathrm{\kappa m}^{2}$. The majority are located on Turkish territory (65\%) and the remainder in the Bulgarian territory (35\%).

91 
Strandzha Mt. is characterized by hilly and low mountain relief. About $22,2 \%$ of the territory of the mountain fall of hypsometric belt of 0 to 200 meters, about $67,5 \%$ - from 200 to 600 meters and $0,3 \%$ are over 600 meters. Dominated by ridges limited by deeply cut river valleys with wide valley floors and steep valley slopes.

The river valleys outline several key ridges in Strandzha Mt. Main orographic and largely hydrographic knot of the entire area is border Kervansaray peak $(632 \mathrm{~m})$, of which are separated many mountain ridges. Southeast of it remains the main ridge of the mountain, with some mountain ridges reaching Bosphorus Strait.

On Bulgarian territory outlines two main ridges spreading in the direction of west-east: South- Granichen („The Border” in Bulgarian), with highest point in the Bulgarian part Gradishte peak (709,6 m) and northernBosna (Papiya peak, $502 \mathrm{~m}$ ), in which from the north direction separate low and hilly ridges- Medni rid („Copper Ridge” in Bulgarian, 376 m high), Rosen bair (267 m), Karatepe (434 m) and Kitka (Uzundzha bair) $(215 \mathrm{~m})$, which ends on the Black Sea coast with the famous Maslen Cape. The main ridge of the mountain, oriented northwest-southeast, is located on Turkish territory. Here is the highest peak of the massif - Golyama Mahiada, 1031 meters high in part Karamustafa bair. In southeast direction its height gradually decreases and ends with Karatepe peak (434 m).

\section{Geologic-tectonic notes}

The most detail geological characteristic of the Sakar-Strandzha morphostructural zone is given on the map sheets (m.s.) and their explanatory note (e.n.) from the Geological map of Bulgaria in a scale 1: 100000 (Edition of the Geological Institute B.A.S. and Committee of Geology, Sofia, 1995 - Bulgarian and English version).

According to her the Strandzha Mountain Massif is occupied by etc. Strandzha anticlinorium, in whose core is represented by metamorphic rocks with Early-Middle Jurassic age overlaid with Late Cretaceous not metamorphosed sedimentary and volcanic rocks represented by shales, phyllites, aleurolites and diabases, sandstones, recrystallized limestones and marbles. Among them in later times are intruded larger bodies by Paleozoic granitoids. The northern part of the mountain massif is occupied by Late Cretaceous andesites, andesite tuffs and sandstones. The southern parts of the area are dominated by Late Jurassic rocks - clays, sandy- clays and marl schists. On the territory of the Mountain Massif also reveal Neogene marine sediments and Quaternary continental and marine sediments. The erosion anywhere is from medium to strong due to specific litogenetic and hydroclimatic features of the natural complex.

The majority of Sakar Mountain is built of granite Batholith with Paleozoic age surrounded by a metamorphic mantle- gneisses, amphibolites, shale, etc., which are significantly broken. The modern appearance of the relief is formed in the Late Tertiary and Quaternary under the influence of vertical movements and erosion-denudation processes.

Dervent hills are built mostly of limestone and granite.

\section{Morphostructural position}

The dome-like morphounits of the Sakar-Strandza morpostructural zone are disposed in the south-east end of the Bulgarian continental microplatte. The Sakar and Dervent morphostructural areas spare the Upper Thracian morphostructural zone from the Lower Thracian morphostructural zone. The Strandzha morphostructural area fall into the scope of the West Black Sea passive continental margin. The most eastern parts of this area show the increase seismic activity. The moderate seismic activity (during the last 50 years) is established in the Sakar morphostructural area and in the boundary zone between the Dervent and Strandzha morphostructural areas. This circumstance is speaking for the continued destruction in the Sakar-Strandzha morphostructural zone.

\section{References}

[1] Chatalov, G., Geologia na Strandzhanskata zona v Bulgaria, S., Izd. BAN, 1990, 263 s.

[2] Galabov, Zh. (red.), Il. Ivanov, P. Penchev, K. Mishev, V. Nedelcheva. Fizicheska geografia na Bulgaria. Narodna prosveta, Sofia, 1956, 344.

[3] Kanev, D. Morfostrukturni zoni i oblasti v Bulgaria. God. Sof. u-tet, 1977, 69, 2, Sofia.

[4] Kanev, D., Geomorfologia na Bulgaria. Univ. izd. "Kliment Ohridski”, Sofia, 1989, 322.

[5] Tsankov, Ts., Kr. Stoyanov. Otnosno geomorfolozhkoto rayonirane na Bulgaria. Sbornik dokladi, Izd.

Sayuz na uchenite - St. Zagora, t. 4, 2003, 50-54.

[6] Katzkov, N., Stoychev, D., Antova, N., Decheva, A., Yovchev, S.,Kuleva, S., Spiridonova, M., Stoyanov, Ts., Filipov, L., Filipova, L. The cosmophototectonic map of Bulgaria. - Geologica Balcanica, 15, 1, 1985, 3 10. 
[7] Tzankov, Tz., C. Burchfiel, L. Royden. Neotectonic (Quaternary) map of Bulgaria - scale 1:500000. NSBN 954 -01 - X. Publishing House Grafica - 19, Sofia, 1998.

[8] Tzankov, Tz., C. Burchfiel, L. Royden. Explanatory Note to the Neotectonic (Quaternary) map of Bulgaria - scale 1:500000. NSBN 954 -01 - X. Publishing House Grafica-19, Sofia, 1998a, 12.

[9] Yaranoff, D. La Neotectonique de la Bulgarie. Revue de Geographie phisique et de Geologie dynamique, 5, 2, Paris, 1963, 75-83.

[10] http://www.noaa.gov/

[11] https://www.iris.edu/hq/ 